\title{
Publications by Adolf SPRUdzs: 1953-2002
}

Edited and Updated by Lyonette Louis-Jacques

\section{Publications}

"Publications By Adolf Sprudzs: 1953 - 1998." International Journal of Legal Information 27:1 (Spring 1999) 5-15.

\section{Books}

Ardievas Laikmetam: Rakstu un runu atlase, 1947-1989 [Latvia: Recollections of an Age] (2001). Http://www.lib.uchicago.edu/ was2/sprudzs/ contents.htm.

Re-building Democracy in Latvia. 33p. 1996. "November 1996." Chicago, 1996.

The Baltic Path to Independence : An International Reader of Selected Articles. Buffalo, N.Y.: Wm. S. Hein \& Co., 1994 (editor).

A Guide to the United States Treaties in Force. Buffalo, N.Y.: Wm. S. Hein \& Co., 1982, 1983, 1984, 1985, 1986, 1987 \& 1988 (with Igor I. KAVASS).

Unpublished and Unnumbered Treaties Index 1986, 1987, 1988. Buffalo, N.Y.: Wm. S. Hein \& Co. (with Igor I. KAVASS). (U.S. Treaty Indexing Service.)

International Legal Research Perspectives. Buffalo, N.Y.: Wm. S. Hein \& Co., 1988.

Current Treaty Index. Buffalo, N.Y.: Wm. S. Hein \& Co. 1982-88 (with Igor I. KAVASS). 
Extradition Laws and Treaties of the United States. Buffalo, N.Y.: Wm. S. Hein \& Co. 1979-date. (2 vols. Looseleaf) (with Igor I. KAVASS).

UST Cumulative Indexing Service 1976: Cumulative Index to United States Treaties and Other International Agreements 1976-date. Buffalo, N.Y.: Wm. S. Hein \& Co., 1978-date. (loose-leaf). (with Igor I. KAVASS).

UST Cumulative Index 1971-1975; Cumulative Index to United States Treaties and Other International Agreements 1971-1975. Buffalo, N.Y.: Wm. S. Hein \& Co. 1977 (with Igor I. KAVASS).

UST Cumulative Index 1950-1970. Buffalo, N.Y.: Wm. S. Hein \& Co., 1973. (4 vols.) (with Igor I. KAVASS).

Chronological Index to Multilateral Treaties in Force for the United States (as on January 1, 1972). Chicago, IL: The University of Chicago Law School Library Publications. Bibliographies and Guides to Research, No. 8 (with the assistance of Peter TRUE).

International Military Law and History Reprint Series. Buffalo, N.Y.: Wm. S. Hein \& Co., 1972-75. (Vols. 1-10) (with Igor I. KAVASS).

Benelux Abbreviations and Symbols-Law and Related Subjects. Dobbs Ferry, N.Y.: Oceana Publications, 1971.

Status of Multilateral Treaties: List of Published Status Charts, Preliminary List No. [1-3]. American Association of Law Libraries, 1971.

Treaty Sources in Legal and Political Research: Tools, Techniques and Problems - The Conventional and the New. Tucson: University of Arizona Press, 1971. [Originally presented as a paper, "Information on Recent Treaties," to the 8th International Congress of Comparative Law, Pescara, Italy, 1970.]

"Information on Recent Treaties : Some Observations on Tools, Techniques, and Problems ; the Conventional and the New", A Paper Submitted to the Special Section of the Eighth International Congress of Comparative Law, August 30 - September 5, 1970, Pescara, Italy. 
Italian Abbreviations and Symbols-Law and Related Subjects. Dobbs Ferry, N.Y.: Oceana Publications, 1969.

Res Baltica: A Collection of Essays in Honor of the Memory of Dr. Alfred Bilmanis (1887-1948). A. W. Sijthoff, 1968 (with Armins RUSIS).

Foreign Law Abbreviations: French. Dobbs Ferry, N.Y.: Oceana Publications, 1967.

The Handling of a Collection of Legal Briefs in a Library Specializing in Briefs and Other Papers Filed with the Court in Automobile, General Liability and Workmen's Compensation Cases. M.A.L.S., Rosary College, paper. River Forest, IL. 1961.

The Annexation of Latvia by the Union of Soviet Socialist Republics. Photocopy. Louvain, Belgium 1953.

The Baltic States and American policy 1940 - 1953: "Mémoire présenté pour l'obtention du grade de Licencié en Sciences Politiques et Sociales; groupe: Relations internationales." Photocopy. Louvain, Belgium 1953.

\section{Articles}

"Dziesmu brînums," in Vadonis : XI Vispârçjie latvieđu dziemsu svçtki ASV Chicago, 2002.

"Rebuilding Democracy in Latvia: Overcoming a Dual Legacy," in Democratic Consolidation in Eastern Europe 1:139-164. Jan ZIELONKA, Alex PRAVDA, eds. Oxford University Press, 2001.

"Ex iniuria ius non oritur' and the Baltic Case: a Brief Western Perspective," in The Baltic States at Historical Crossroads: Political, Economic, and Legal Problems in the Context of International Cooperation on the Doorstep of the 21st Century: A Collection of Scholarly Articles Published in Remembrance of Senator August Loeber and the 75th Birthday of Professor Dietrich André Loeber 651-663, Dr. Tâlavs JUNDZIS, ed. Academy of Sciences of Latvia 1998. 
"Dîtrihs Andrejs Lçbers - Zinâtnieks ar Pasaules Vârdu. [Dietrich André Loeber - An Internationally Known Scholar]," in Latvijas zinâtnu akadçmijas ârzemju loceklis : Dîtrihs Andrejs Lçbers : biobibliografija / sast. M. KADIKE, G. Đtâle, Dz. ZAKE. Latvijas Akadçmiskâ bibliotçka, 1997.

"Thirty-five Years of International Cooperation: The Case of the IALL, " Law Librarian 26:321 (1995).

"Introducing the Baltic Story," in The Baltic Path to Independence: An International Reader of Selected Articles vi-xvi. Buffalo, N.Y.: Hein, 1994.

"A Baltic Chronology of Selected Significant Events, 1987-1991, " in The Baltic Path to Independence: An International Reader of Selected Articles 381. Hein 1994.

"The Rule of Law and the Baltic States [with Annex - Declaration of Restoration of Latvian Independence], " in Bibliothek und Rechtinternational. Libraries and Law - International: Festschrift Ralph Lansky, by Jürgen Christoph GöDAN \& Holger KNUDSEN, eds. (1991).

"The International Association of Law Libraries and its Twenty-five Years of Activities," The Law Librarian 15:50 (1984).

"Fundamentals of Foreign Treaty Research," (International Law Symposium). Law Librarian Journal 76:458 (1983).

"International Legal Research: An Infinite Paper Chase," (Symposium: International Legal Research Methodology). Vanderbilt Journal Transnational Law 16:521 (1983).

"Problems with Sources of Information in International Law and Relations: The Case of the World-Wide Treaty Jungle," International Journal of Law Libraries 9:195 (1981). [Originally presented as a paper before the Section of Social Science Libraries at the 47th Annual IFLA Conference, August 1981 in Leipzig].

"IALL Week in Manila," International Journal of Law Libraries 8:193 (1980). 
"The International Encyclopedia of Comparative Law: A Bibliographical Status Report," American Journal of Comparative Law 28:93 (1980).

"Die Amerikanische Vereinigung der Rechtsbibliotheken: eine Skizze," Mitteilungen [der Arbeitsgemeinschaft für juristisches Bibliotheks-und Dokumentationswesen] 9:63 (1979). [Expanded version of a lecture presented before the Arbeitsgemeinschaft für juristisches Bibliotheksund Documentationwesen, June 1979 in Berlin.]

"Latvia." In: Constitutions of Dependencies and Special Sovereignties. Dobbs Ferry, N.Y.: Oceana Publications 1978.

"Basic U.S. Sources for Current Research in International Law: An Elementary Vade-Mecum," International Journal Law Libraries 5:347358 (1977).

"Comments on Foreign Law Surveys," International Journal of Law Libraries 2:84-87 (1974).

"Status of Multilateral Treaties-Researcher's Mystery, Mess or Muddle?" American Journal of International Law 66:365-376 (1972).

"International Co-operation and the Status Information on Multilateral Treaties in Force," International Association of Law Libraries Bulletin, December 41-44 (1972).

"Dr. Alfred Bilmanis and His Struggle for Freedom of the Baltic States," in Res Baltica 11 (Sijthoff 1968).

"International Association of Law Libraries is Launched," Libri 9:262-263 (1959).

\section{Bibliographies}

"Bibliography of Max Rheinstein's Writings," University of Chicago Law Review 45:489-510 (1978).

"Dr. A. Bilmanis' Writings: A Selected Bibliography," in Res Baltica 286. Leyden: Sijthoff, 1968. 
"Legal Aspects of Yugoslav Foreign Trade-A Selected Bibliography," in Consultation with Djurica Krstic 1968. The University of Chicago Law School Library Publications. Bibliographies and Guides to Research, No. 3.

"Max Rheinstein's Writings: A Bibliography Published by the University of Chicago Law School on the Occasion of Professor Rheinstein's Retirement." Chicago, 1968.

"Selected Bibliography on International Trade, Investment, and Organization," in International Trade, Investment, and Organization 478, by Wayne R. LAFAve \& Peter HAY (eds.) U. of Illinois Press, 1967. [Originally published in University of Illinois Law Forum, 1965, Winter Issue, 872].

"The Hague Scholars: Index to Portraits, Biographies, and Principal Publications of Scholars Who Lectured at The Hague Academy of International Law from 1947 to 1966," (as published in Recueil des cours, tomes 70-117). Chicago, 1967. (University of Chicago Law School Library Publications. Bibliographies and Guides to Research, No. 2).

\section{Book Reviews}

"Bibliography of Hungarian Legal Literature: 1945:1980," by Lajos NAGY, International Journal of Legal Information 17:164 (1989).

"Bibliographie juristischer Festschriften und Festschriftenbeiträge: Deutschland, Schweiz, Österreich," by Helmut DAU, International Journal of Legal Information 17:298 (1989).

"The Annexation of the Baltic States and Its Effect on the Development of Law Prohibiting Forcible Seizures of Territory," by William J. H. HoUGH, III. Journal of Baltic Studies 18:95 (Spring, 1987).

"Bibliographie juristischer Festschriften und Festschriftenbeiträge: Deutschland, Schweiz, Österreich," by Helmut DAU, International Journal of Legal Information 15:154 (1987). 
"United States Treaties, Executive Agreements and Guide to Participation in International Organizations," International Journal of Legal Information 14:75 (1986).

"International Law of the Sea and Marine Affairs: A Bibliography; supplement to the 1980 edition," by Nikos PAPADAKIS and Martin GLASSNER, International Journal of Legal Information 12:274 (1984).

"Deutsche Rechtsbibliographie 1982," by Klaus MENZINGER, International Journal of Legal Information 12:290 (1984).

"Grundliteratur Recht: Bundesrepublik Deutschland; eine Auswahlbibliographie;" by Ralph LANSKY, International Journal of Legal Information 12:291 (3rd edition 1984).

"Bibliographie juristischer Festschriften und Festschriftenbeitrage: Deutschland - Schweiz - Österreich, 1864-1944," by Helmut DAU, International Journal of Legal Information 12:295 (1984).

"Doing Business in France," by Simeon MOQUET \& Associés, International Journal of Legal Information 12:54 (1984).

"Dansk juridisk bibliografi: 1972-1980," by Jens SONDERGAARD, International Journal of Legal Information 11:316 (1983).

"Countries of the World and Their Leaders Yearbook, 1983," International Journal of Legal Information 11:319 (1983).

"Directory of Libraries in Singapore," by Yok Fong SNG, Siew Kheng LAU \& Guan Fong KHOO, International Journal of Legal Information 11:322 (3d edition 1983).

"Development of Judicial Control of the European Communities, " by Gerhard BEBR, International Journal of Legal Information 11:29 (1983).

"Codice delle convenzioni di diritto internazionale privato e processuale," M. GiUliano, F. POCAR \& T. TREVES, International Journal of Legal Information 10:73 (2d edition 1982). 
"John Henry Wigmore," by Albert KoCOUREK \& Kurt SCHWERIN, International Journal of Legal Information 10:202 (1982).

"International Handbook of Contemporary Developments in Librarianship," by Miles M. JACKSON, International Journal of Legal Information 10:203 (1982).

"Zeitschrift für neuere Rechtsgeschichte 'ZNR'," by Wilhelm BRAUNEDER, Pio CARONI, Bernhard DIESTELKAMP, Clausdieter SCHOTT \& Dietmar WILLOWEIT (eds.), International Journal of Legal Information 10:88 (1982).

"Staatsrecht - Völkerrecht - Europarecht," by Ingo VON MUNCH, International Journal of Legal Information 10:22 (1982).

"World Bibliography of International Documentation," International Journal of Legal Information 10:34 (1982).

"Handbuch der Bibliographien zum Recht der Entwicklungsländer, " by Ralph LANSKY, International Journal of Legal Information 10:37 (1982).

"Lambert's Worldwide Government Directory with Inter-governmental Organizations 1981," by Diane E. HRABAK, International Journal of Legal Information 10:42 (1982).

"Festschrift für Konrad Zweigert zum 70. Geburtstag," by Herbert BERNSTEIN, Ulrich DROBNIG \& Hein KÖTZ, International Journal of Law Libraries 9:234 (1981).

"Bibliotheksarbeit für Parlamente und Behörden: Festschrift zum 25 jährigen Bestehen der Arbeitsgemeinschaft der Parlaments- und Behördenbibliotheken," by Wolfgang DIETZ, Hildebert KIRCHNER \& Kurt Georg WERNICKE," International Journal of Law Libraries 9:239 (1981).

"Italy and the Law of the Sea Newsletter," by Tullio TREVES, International Journal of Law Libraries 9:240 (1981).

"The Austrian Banking System under the 1979 Statute," by Edith PALMER, International Journal of Law Libraries 9:241 (1981). 
"Legal Thesaurus," by William C. BURTON, Steven DeCosta \& Michael Hoschander MALEN, International Journal of Law Libraries 9:242 (1981).

"Bibliography of Works on the Law of the United States in Foreign Languages," by Marie-Louise H. BERNAL \& Ivan SIPKOV; with editorial assistance by E. Jeanne TEMPLE, International Journal of Law Libraries 9:243 (1981).

"Die europäischen Interessenverbände und ihre Beziehungen zum Wirtschaftsund Sozialausschuss," International Journal of Law Libraries 9:177 (1981).

"A Collection of Treaties and Other Documents Affecting the States of Malaysia 1761-1963," International Journal of Law Libraries 9:180 (1981).

"Rechtliche und wirtschaftliche Beziehungen zwischen den Integrationsraumen in West- und Osteuropa," by Gottfried ZIEGER \& Axel LEBAHN, International Journal of Law Libraries 9:135 (1981).

"Die Tätigkeit der Europäischen Gemeinschaft unter Einsatz ihrer FinanzInstrumente; Dokumentation," International Journal of Law Libraries 9:137 (1981).

"Organe der erweiterten Europäischen Gemeinschaften," by Helmut Schmitt VON SYDOW \& Georg ROSENBACH, International Journal of Law Libraries 9:137 (1981).

"The Oxford Companion to Law," by David M. WALKER, International Journal of Law Libraries 9:30 (1981).

"Dokumente und Publikationen der Vereinten Nationen und der Sonderorganisationen, " by Otto STEINER, International Journal of Law Libraries 9:38 (1981).

"Parliamentary Librarianship in the English-speaking World," by Philip LAUNDY, International Journal of Law Libraries 9:39 (1981). 
"Acronyms Relating to International Development," by Margaret CARROLL, International Journal of Law Libraries 9:40 (1981).

"A Marine Affairs Bibliography," by Christian L. WIKTOR \& Leslie FosTER, International Journal of Law Libraries 9:40 (1981)

"Who's Who in the Arab World," International Journal of Law Libraries $8: 188$ (5th ed.1980).

"Review of Industrial Property Glossary," prepared by the World Intellectual Property Organization, International Journal of Law Libraries 8:137 (1980).

"Index-Guide to Treaties: Based on the Consolidated Treaty Series," edited and annotated by Clive PARRY, and All Other Series Therein Utilized, Chronological List, 1648-1809. v. 1, by Paul C. IRWIN. International Journal of Law Libraries 8:67 (1980).

"Gesammelte Schriften/Collected Works of Max Rheinstein," edited by Hans G. LESER, International Journal of Law Libraries 8:45 (1980).

"Guide to United Nations Organization, Documentation and Publishing," by Peter HAJNAL, Library Quarterly 49:477 (1979).

"Bibliographie Juristischer Festschriften und Festschriftenbeiträge: Deutschland-Schweiz-Österreich, 1967-1974," by Helmut DAU, American Journal of Comparative Law 26:678 (1978).

"Über die Veröffentlichungspraxis Oberster und Höherer Gerichte in Westeuropa," by Georg LEISTNER, America Journal of Comparative Law 26:132 (1978).

"Cumulative List and Index of Treaties and International Agreements Registered on File and Recorded with the Secretariat of the United Nations December 1969 - December 1974," by Jospeh Thomas VAMBERY. America Journal of International Law 72:962 (1978).

"Bibliographie Rechtswissenschaftlicher Schriftenreihen, A Bibliography of German Language Legal Monograph Series," by Kurt SCHWERIN. International Journal of Law Libraries 6:220 (1978). 
"Calendar of Diplomatic Affairs, Democratic People's Republic of Korea 1945 to 1975 ," by George Ginsburgs \& Roy U. T. KIM. International Journal of Law Libraries 5:255 (1977).

"Handbuch der Bibliographien zum Recht der Entwicklungsländer," by Ralph LANSKY. International Journal of Law Libraries 5:254 (1977).

"Bibliography of International Law," by Ingrid Detter DELUPIS. International Journal of Law Libraries 4:160 (1976).

"I.L.O. Legislative Series (1919-1970) in Microfiche and The Consolidated Index to the I.L.O. Legislative Series (1919-1970)," by Mina PEASE. Law Library Journal 69:114 (1976).

"Abbreviations' Guide to French Forms in Justice and Administration and Arbeitshilfen zum Französischen Recht," by Georg LEISTNER. International Journal of Law Libraries 4:65 (1976).

"Mitteilungen der Arbeitsgemeinschaft für Juristisches Bibliotheks-und Documentationswesen, 1971-1975," by Renate BELLMAN (ed.). International Journal of Law Libraries 4:66 (1976).

"International Government Organizations: Constitutional Documents, " revised 3d edition by Amos J. PEASLEY. Law Library Journal 69:117 (1976).

"Reader in Documents of International Organizations," by R. STEVENS \& H. STEVENS (eds.). Library Quarterly 45:325 (1975).

"Sources, Organization, Utilization of International Documentation: Proceedings of the International Symposium on the Documentation of the United Nations and Other Intergovenmental Organizations, Geneva, 21-23 August 1972." International Journal of Law Libraries 3:111 (1975).

"Die Auslegung Mehrsprächiger Verträge," by Meinhard HILF. American Journal of Comparative Law 23:592 (1975).

"Liste des Engagements Bilatéraux et Multilatéraux au 30 Juin 1972: Accords et Traités Souscrits par la France," by Henry Rollet. America Journal of International Law 69:461 (1975). 
"Catalogue of International Law (University of Cambridge, Squire Law Library)," compiled by M. A. LEKNER under the direction of W. A. STEINER, 4 vols. The Library Quarterly 43:252 (1973).

"Bibliographie zur Verfassungsgerichtsbarkeit des Bundes und der Länder," by J. MACKERT \& F. SCHNEIDER. American Journal of Comparative Law 21:356 (1973).

"The Legal and Practical Aspects of Trade with the Soviet Union," by James Henry GIFFEN. Law Library Journal 64:98 (1971).

"Guide to Foreign Legal Materials: Belgium-Luxembourg-Netherlands," by Paul GrAULICH, et al. Law Library Journal 62:325 (1969). 